\title{
Pigment identification of an illuminated mediaeval manuscript De Civitate Dei by means of a portable Raman equipment ${ }^{\dagger}$
}

\author{
Debbie Lauwers, ${ }^{a *}$ Vincent Cattersel, ${ }^{\mathrm{b}}$ Ludo Vandamme, ${ }^{\mathrm{c}}$ Annabel Van Eester, \\ Kaat De Langhe, ${ }^{\mathrm{e}}$ Luc Moens $^{\mathrm{a}}$ and Peter Vandenabeele ${ }^{\mathrm{e}}$
}

Direct identification of pigments in mediaeval illuminated manuscripts was one of the first applications of Raman spectroscopy in art and archaeology. In previous in situ analysis of handwritings, the equipment was typically provided with a single excitation source. In this work, a portable Raman spectrometer (EZRAMAN-I-DUAL Raman system) is introduced to characterise the pigments used in an important illuminated mediaeval manuscript, De Civitate Dei (Library in Bruges, Ms.106). Characteristics important for these in situ measurements were discussed. We introduce a set-up that allows stable positioning of the equipment and point out the advantage of the availability of two lasers, which are part of the instrument. Good performance of the introduced Raman spectrometer, to allow pigment identification in a short time, is proved. Finally, pigments such as lead white $\left(2 \mathrm{PbCO}{ }_{3} \cdot \mathrm{Pb}(\mathrm{OH})_{2}\right), l$ lead-tin yellow type I $\left(\mathrm{Pb}_{2} \mathrm{SnO}_{4}\right)$, malachite $\left(\mathrm{Cu}_{2} \mathrm{CO}_{3}(\mathrm{OH})_{2}\right)$, mosaic gold $\left(\mathrm{SnS}_{2}\right)$, vermillion $(\mathrm{HgS})$, carbon black $(\mathrm{C})$, red lead $\left(\mathrm{Pb}_{3} \mathrm{O}_{4}\right)$ and azurite $\left(\mathrm{Cu}_{3}\left(\mathrm{CO}_{3}\right)_{2}(\mathrm{OH})_{2}\right)$ could be identified. These pigments were often used in mediaeval artworks and contribute to the enrichment of information of the materials used by the illuminator. Copyright @ 2014 John Wiley \& Sons, Ltd.

Additional supporting information may be found in the online version of this article at the publisher's web site.

Keywords: portable Raman spectroscopy; illuminated manuscript; pigments; archaeometry

\section{Introduction}

Direct identification of pigments in mediaeval illuminated manuscripts was one of the first applications of Raman spectroscopy in art and archaeology. ${ }^{[1-3]}$ The analytical investigation of pigments is an important aspect of the technical characterisation of (art) historical objects. ${ }^{[4,5]}$ It can reveal important information relevant to dating and authentication, conservation or restoration of art. ${ }^{[4,6]}$

Micro-Raman spectroscopy is well known for its non-destructive character, molecular specificity, spatial resolution and its suitability for in situ characterisation of illuminated manuscripts. ${ }^{[7-11]}$ Direct analysis can be performed in the lab or on the field, depending on the size of the artefact and the ability to transport the object. ${ }^{[12-17]}$ If transportation of the book is not allowed, analytical approaches are available: (i) sampling via the Q-tip method as previously reported ${ }^{[18]}$ or (ii) direct analysis with a mobile instrument. Often, despite the possible interference of fluorescence from support and binders, ${ }^{[14,19]}$ on-site analysis is preferred over sampling (Q-tip) due to the limited, thin paint layers used in miniature art (which can impede the sampling). ${ }^{[20,21]}$

In previous in situ analysis campaigns of manuscripts, the equipment was typically provided with a single excitation source. ${ }^{[22-24]}$ Nevertheless, the ability to switch between different lasers is extremely useful, as absorption of the scattered light by the sample may result in a reduced spectral quality of the Raman spectrum. ${ }^{[2,26]}$ Moreover, in some cases, wavelength-dependent fluorescence can be overcome by using a different excitation laser. Therefore, in this work, a portable Raman spectrometer (cf. definition formulated elsewhere, ${ }^{[27,28]}$ ) equipped with two lasers, is introduced to characterise the pigments present in the mediaeval De Civitate Dei manuscript from the cultural heritage library in Bruges. The pigment identification will contribute to the enrichment of information of the working practice and materials used by the illuminator.

\section{Experimental}

In situ Raman spectroscopy was performed on a selection of illuminated folios in the manuscript De Civitate Dei. On folio 1 (recto,r), the decorative fleuronnée initial of the letter ' $A$ ' was examined. The miniature on folio $22 r$ was also a region of great

\footnotetext{
* Correspondence to: Debbie Lauwers, Department of Analytical Chemistry, Ghent University, Krijgslaan 281 (S-12), B-9000 Ghent, Belgium.

E-mail: Raman@Ugent.be

+ This article is part of the special issue of the Journal of Raman Spectroscopy entitled "Raman in Art and Archaeology 2013" edited by Polonca Ropret and Juan Manuel Madariaga.

a Department of Analytical Chemistry, Ghent University, Krijgslaan 281 (S-12), B-9000 Ghent, Belgium

b Faculty of Design Sciences, Artesis University College Antwerp, Blindestraat 9, $B-2000$ Antwerp, Belgium

c Public library Biekorf, Kuipersstraat 3, B-8000 Bruges, Belgium

d Artesis Academy of Antwerp, Blindestraat 9, B-2000 Antwerp, Belgium

e Department of Archaeology, Ghent University, Sint-Pietersnieuwstraat 35, B-9000 Ghent, Belgium
} 
interest, because it was attributed to the illuminator Willem Vrelant (or his workshop) by F. Lyna and G. Bousmanne. ${ }^{[29,30]}$ The studied folios and the examined areas are shown in Fig. 1. A digital version of the manuscript can be found on the website of the cultural heritage library in Bruges. ${ }^{[31]}$

\section{Reagents}

Pigments labelled 'lead white' $\left(2 \mathrm{PbCO}_{3} \cdot \mathrm{Pb}(\mathrm{OH})_{2}\right)$, 'atacamite' $\left(\mathrm{Cu}_{2} \mathrm{Cl}(\mathrm{OH})_{3}\right)$, 'cobalt blue' $\left(\mathrm{CoAl}_{2} \mathrm{O}_{4}\right)$ and 'red lead' $\left(\mathrm{Pb}_{3} \mathrm{O}_{4}\right)$ were obtained from Kremer, Aichstetten, Germany.

\section{Instrumentation}

All measurements were performed by a portable EZRAMAN-I-DUAL Raman system (Enwave Optronics, Irvine CA, USA). ${ }^{[27]}$ The fibre optic-based spectrometer is equipped with two lasers, a red diode laser $(785 \mathrm{~nm})$ and a green Nd:YAG laser $(532 \mathrm{~nm})$, and a CCD detector. For each wavelength, three interchangeable lenses are foreseen: a standard lens (circular spot size of $0.074 \pm 0.002 \mathrm{~cm}$ ), a contact lens and a high numerical aperture lens (circular spot size of $0.088 \pm 0.002 \mathrm{~cm}$ ). The power of the laser can be set, using an adjustable power controller for each laser (maximum output power 400 and $100 \mathrm{~mW}$ for 785 and $532 \mathrm{~nm}$ lasers, respectively). Depending of the selected laser, a different spectral range and thus a different diffraction grating is used. The $785 \mathrm{~nm}$ laser records Raman signals between 100 and $2350 \mathrm{~cm}^{-1}$ (spatial frequency of grating is $1200 / \mathrm{lpmm}$ ), while the green $532 \mathrm{~nm}$ laser has a spectral range of $100-3200 \mathrm{~cm}^{-1}$ (spatial frequency of grating is 1800 / Ipmm). Consequently, the spectral resolutions are different, namely 5.67 and $6.94 \mathrm{~cm}^{-1}$, for the 785 and $532 \mathrm{~nm}$ lasers, respectively. The Raman spectrometer was applied by using $230 \mathrm{VAC}$ but note that the instrument can also be operated by using an internal or external Li-battery (Enwave Optronics).

The recorded Raman data were processed using Thermo Grams/AI $8.0{ }^{\circledR}$ suite software (Thermo Galactic).

\section{The mediaeval manuscript De Civitate Dei (Ms.106)}

Since the original version of the De Civitate Dei was written in the fifth century, by the early theologian and philosopher Aurelius
Augustine, this 22-chapter Latin-written manuscript has been very influential for Western Christian societies throughout the middle ages. Proof of its popularity can be found in the fact that almost 450 copies of this work are still preserved to date. ${ }^{[32]}$

In this research, an important copy of the De Civitate Dei, which is preserved at the public library Biekorf in Bruges, is examined. It was produced in the second half of the 15th century and ended up in Bruges in the 17th century, foreseen of a so-called Campmansstrap (after Bernard Campmans, the 40th abbot of the abbey Ten Duinen) and a cross of Ten Duinen. This indicates that the manuscript was once part of the Cistercian libraries. Although the cross of Ten Duinen denotes the provenance of the manuscript from the abbey Ten Duinen (Koksijde, Belgium), the book can also come from the abbey Ter Doest (a daughter foundation of Ten Duinen), because of the fusion of the abbeys.

Codicological research (i.e. a microscopic study of the parchment support) supported the estimation of the manuscript production during the 15th century. It showed that a high density of hair follicles are uniformly distributed throughout the parchment surface, which are representative for parchment made from calf skin. It is known that the use of this skin was widespread for this region throughout the 15th century. ${ }^{[33]}$

The content of the manuscript focuses on Christian philosophy, more specific on the dualism between good and evil. The book is decorated with some colourful illuminations, which are created in the 'Ghent-Bruges' style and can be attributed to Willem Vrelant, who was an active member of the Saint John the Evangelist Guild. ${ }^{[18,29]}$ The latter was exclusively reserved for craftsmen that were related to production and trade of manuscripts. Vrelant was most active during the third quarter of the 15th century and is considered as one of the most influential and commercially successful illuminators of his time. His distinctive technique and pictorial vocabulary can be described as rather conservative for the time. Most recognisable in his oeuvre are the static figures, 'oval faces, straight and slender noses, high and wide foreheads and the figures lacking personality'. ${ }^{[30]}$

\section{Results and discussion}

Technical aspects of miniature art can be studied via sampling and via direct analysis. Due to the limited materials, the preciousness
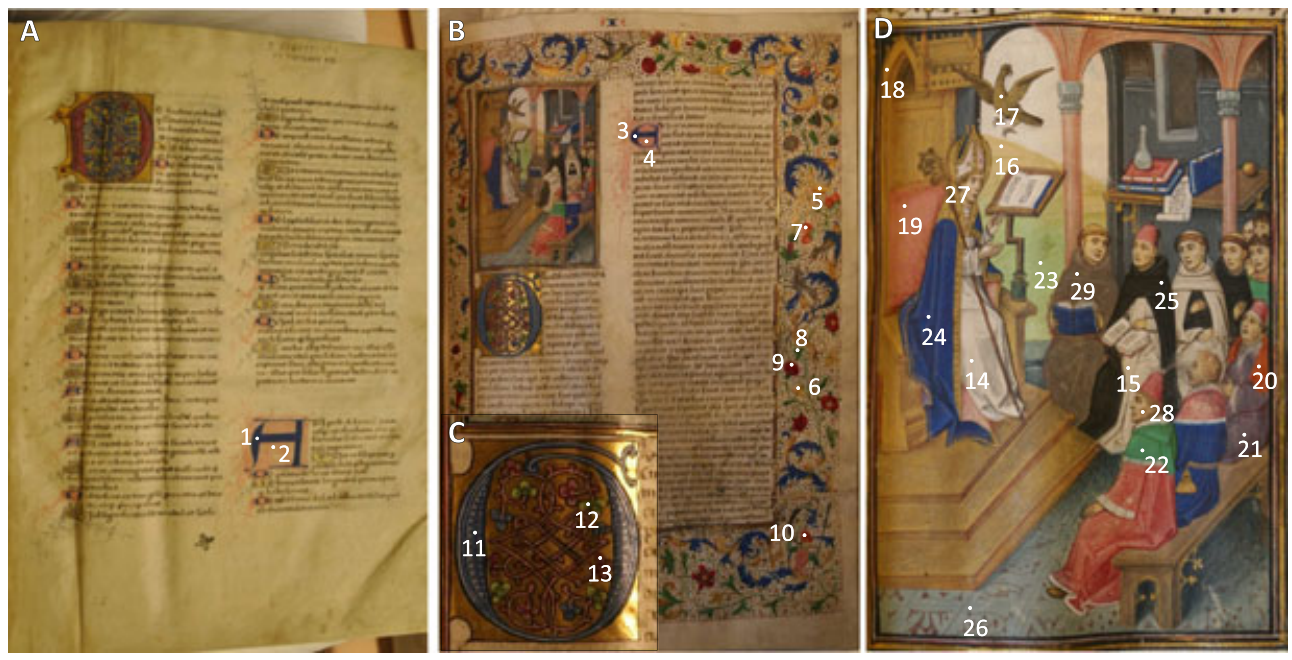

Figure 1. (A) Ms.106, f1r, Litterae duplex; (B) Ms. 106, f22r, Litterae duplex and border decoration; (C) Ms.106, f22r, detailed picture of the decorated initial; (D) Ms.106, f22r, miniature of Sint-Augustinus who is teaching the audience. 
and fragility of the manuscript, non-destructive investigation was chosen, more specific in situ Raman analysis.

Raman spectroscopy was performed on the illuminated manuscript by means of a portable dual-laser Raman instrument. This spectrometer is $43 \times 33 \times 18 \mathrm{~cm}$ and weighs $17 \mathrm{~kg}$. A schematic overview of the inside composition of the portable Raman spectrometer is given in Fig. S1 (Supporting information).

When analysing art objects directly, good quality positioning (i.e. focusing) of the equipment is of utmost importance to obtain high quality results. ${ }^{[34]}$ It is required to have stable equipment and the way the instrument is mounted must be safe. Apart from the requirement for stable positioning equipment, it should also allow easy macro and micro-positioning. The set-up used for direct analysis is shown in Fig. 2. The probeheads were mounted on an articulating $\mathrm{arm}{ }^{[35]}$ using an in-house developed clam. This clam can also hold a digital microscope camera (Dyno-lite), which allows illuminating and recording of the region of interest and is connected to the spectrometer via the universal serial bus port of the build-in laptop. Correct and easy positioning is made possible due to the presence of micrometre translation stages, which can be operated manually. This set-up also provides the advantage of allowing switching easily between both lasers, 785 and $532 \mathrm{~nm}$ lasers, to use the preferred laser wavelength for a coloured area. ${ }^{[19]}$ Switching is done rather quickly (200 s) and easily: the spectrometer is equipped with a switch button and is also provided with two operation software's, one for each laser. To exchange between lasers, the software of the one laser has to be closed, and the cooling system needs to be turned off, using a central key. Next, the switch button has to be turned to the preferred laser, and the cooling system can be turned on again, together with starting up the software of the corresponding laser.

To avoid damage to the manuscript (e.g. crumbling of the leather or parchment, peeling off the back or cover of the manuscript), book pillows and V-shaped foam were used to open it. If needed also, lead laces were applied to keep manuscript folios in place.

In the next part, we will discuss some features that are of importance to direct analysis, applied to the investigation of the De Civitate Dei manuscript.

\section{Characteristics important to in situ analysis}

When performing analysis in musea, libraries, etc., the availability of the object is often limited in time. This means that the analyst

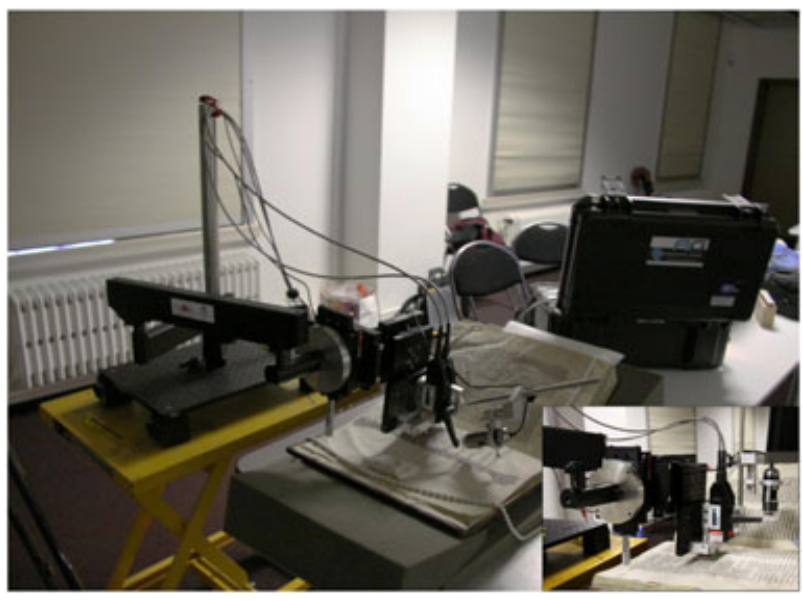

Figure 2. General overview of the set-up. has to plan well, in order to execute a complete characterisation of the object quickly. In this project, two approaches were taken into account: (i) obtain excellent quality spectra of a selection of paint colours and (ii) characterise as much as possible, i.e. record one spectrum (max. three) of each paint colour with a relatively good spectral quality (reasonable signal-to-noise ratio, SNR), in a short time. The selection of one of the approaches depends on the intended purpose. When the analyst wants to compare the composition of similar colours or identify degradation products (results in weak Raman bands), it is better to obtain excellent quality spectra. If he wants to obtain information about the total used artist's palette, the second perspective is preferred. The latter approach was selected for the analysis of this mediaeval manuscript. Note that in this case, the Raman spectra (within short measuring time) are obtained probably at the expense of the spectral quality. Fig. 3 represents some of the Raman spectra that were recorded in only $30 \mathrm{~s}$. As one can see, clear bands could be detected in a short time, with a good SNR. This proves that the introduced Raman spectrometer is highly performant to allow pigment identification in a short time, with reasonable spectral quality. As a result, all the paint colours at the selected regions (28 points), present in the folios, could be examined.

As mentioned, two lasers (785 and $532 \mathrm{~nm}$ ) can be used during the analysis of the De Civitate Dei manuscript, between which we can switch. This can lead to successful identification of pigments: as some pigments yield weak spectra with one of the lasers (i.e. low SNR), better results can be obtained with the other one.

Some measurements were performed in the lab to point out the benefit of dual laser excitation. Raman spectra were recorded of several reference pigments with both lasers. In this paper, we selected four pigments (labelled by Kremer pigmente as lead white, atacamite, cobalt blue and red lead) for which the need of two lasers becomes clear. Fig. S2 represents the Raman spectra recorded of the four pigments with both excitation sources. Cobalt blue and red lead prove to be good scatterer for the red laser but show clear absorption interference for the $532 \mathrm{~nm}$ laser, resulting in weak Raman bands. The green pigment labelled atacamite, on the other hand, strongly absorbs the red laser and can burn already with a low laser power. In this case, the green laser is the optimal laser to use; this is true for most blue and green pigments. Note, when taking a closer look to the recorded spectrum of atacamite (Kremer), it was clear that it doesn't correspond to the spectrum of this compound. Comparing this spectrum with reference spectra of malachite and atacamite from the database of RRUFF, ${ }^{[36]}$ it was found that we are dealing with malachite instead of atacamite (Fig. S3). On the basis of the findings in the preceding text, it is clear that the presence of two lasers can lead to more successful identification of materials. Not every pigment is only Raman active for a certain laser wavelength: lead white for example results in a good Raman spectrum for both excitation wavelengths (Fig. S2).

To prove this concept, the instrument was tested on the manuscript: the blue area of the decorated initial (f22r, point 11) was analysed with both lasers. The spectra were recorded with a total measured time of $150 \mathrm{~s}$, using the STD lens. Although both spectra are noisy, the SNR is much better for the green laser than for the red laser (Fig. 4). Studying the detected band position, the blue pigment used for the illumination could be identified as azurite $\left(\mathrm{Cu}_{3}\left(\mathrm{CO}_{3}\right)_{2}(\mathrm{OH})_{2}\right)$. Azurite was an important blue mineral in the middle ages and has characteristic Raman bands at 405 (vs) and 1093 (s) $\mathrm{cm}^{-1}$, due to $\mathrm{Cu}-\mathrm{O}$ stretching 

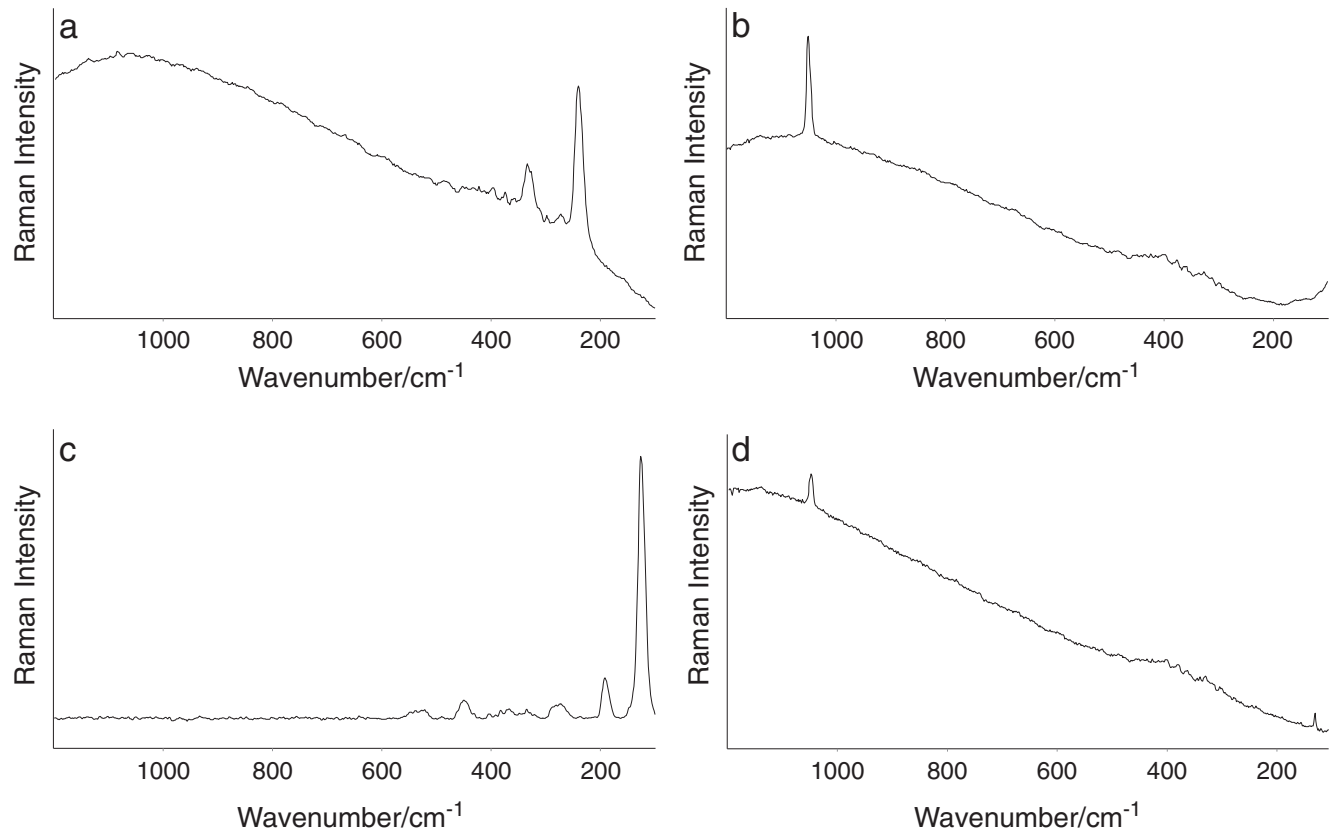

Figure 3. Raman spectra are recorded with the $785 \mathrm{~nm}$ laser with only $30 \mathrm{~s}$ of accumulation time (baseline corrected), from the mediaeval manuscript, De Civitate Dei. (a) Spectrum of a red area (f22r, border decoration, point 10). Features of vermillion can be recognised; (b) spectrum of a white area (f22r, miniature, point 15), which can be assigned to lead white; (c) spectrum of a yellow area (f22r, miniature, point 16) with features of lead-tin yellow type l; and (d) spectrum of the incarnation (f22r, miniature, point 27$)$, which is a mixture of lead white and lead-tin yellow type I.

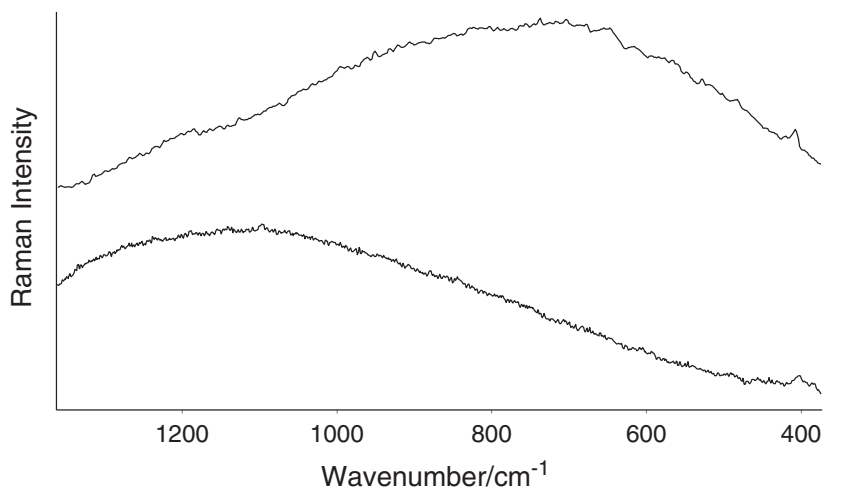

Figure 4. Raman spectra $(30 \times 2 \mathrm{~s}$, STD lens, $70 \mathrm{~mW}$, external power source) of: top: Raman spectra of the unknown blue colour recorded with the $532 \mathrm{~nm}$ laser, identified as azurite $\left(\mathrm{Cu}_{3}\left(\mathrm{CO}_{3}\right)_{2}(\mathrm{OH})_{2}\right)$; bottom: Raman spectra of the unknown blue colour recorded with the $785 \mathrm{~nm}$ laser, identified as azurite $\left(\mathrm{Cu}_{3}\left(\mathrm{CO}_{3}\right)_{2}(\mathrm{OH})_{2}\right)$.

vibration and the symmetrical stretch vibration of the carbonate ion, respectively. The intensity of the bands can differ, depending on the orientation, because azurite is anisotropic: the spectrum is strongly orientation-dependent. ${ }^{[37]}$

\section{Pigment identification of the De Civitate Dei manuscript}

The different colours were examined using the Enwave Raman spectrometer, in the border illumination ( $\mathrm{f} 22 \mathrm{r}$ ), a decorated initial ( $\mathrm{f} 22 \mathrm{r}$ ), fleuronée-initials, more specific litterae duplex ( $\mathrm{f} 1 \mathrm{r}$ and $\mathrm{f} 22 \mathrm{r}$ ) and the miniature $(\mathfrak{f} 22 \mathrm{r})$, ascribed to Willem Vrelant.

The litterae duplex, in both folios, was written by using a combination of red and blue ink. ${ }^{[38]}$ For both initials, vermillion $(\mathrm{HgS})$ was used as a pigment in the red ink. Unfortunately, the composition of the blue ink could not be determined (Table S1) due to very strong fluorescence: this may arise from the binding agent ${ }^{[39-41]}$.The decorated initial, on the other hand, was painted with four pigments: an unknown red (probably organic) pigment, azurite $\left(\mathrm{Cu}_{3}\left(\mathrm{CO}_{3}\right)_{2}(\mathrm{OH})_{2}\right)$ for the blue colour and malachite $\left(\mathrm{Cu}_{2} \mathrm{CO}_{3}(\mathrm{OH})_{2}\right)$ for the green colour (Table S1). In this latter zone also, lead-tin yellow type I $\left(\mathrm{Pb}_{2} \mathrm{SnO}_{4}\right)$ was detected: it was used to create a lighter hue in some areas.

The selected regions of the border decoration and miniature contain blue, white, green, yellow, black, brown, grey, orange, gold and different red paints (Table S1). When investigating the green leaf of the border decoration, a remarkable identification was carried out: an exact match was found with chrome yellow $\left(\mathrm{PbCrO}_{4}\right.$, bands at 840 and $358 \mathrm{~cm}^{-1}$ ) (Fig. 5a). On the basis of microscopic evaluation, it is difficult to say whether the green colour was obtained by a mixture of a blue pigment and a yellow pigment or if a green pigment was used in combination with the yellow pigment to soften the colour. The reason why we were not able to detect the additional Raman bands of the green or blue pigment, lies in the fact that these pigments are weak Raman scatters. It is likely that these bands are masked by the strong scatterer lead chromate. Chrome yellow is an artists' pigment that was commonly used after the mid of the 19th century. ${ }^{[42]}$ This proves that this pigment could not be used in the original colour palette and thus points out a probable restoration of the manuscript during the 19th century. It is known that in 2006 a restoration was executed by BVBA De Zilveren Passer. During this intervention, mainly the structural elements were stabilised. It is not clear if also interventions were made on the illuminations.

Another important colour in the investigation of the border decoration and miniature is the gild. The question arises if the gild is actual gold or mosaic gold, i.e. tin sulphide $\left(\mathrm{SnS}_{2}\right) \cdot{ }^{[43]}$ On the basis of visual investigation, the golden colour has been painted, not gilded. ${ }^{[4]}$ The analysis showed that in the border decoration, probably metallic gold was used because of the absence of Raman bands and the presence of a high fluorescence 

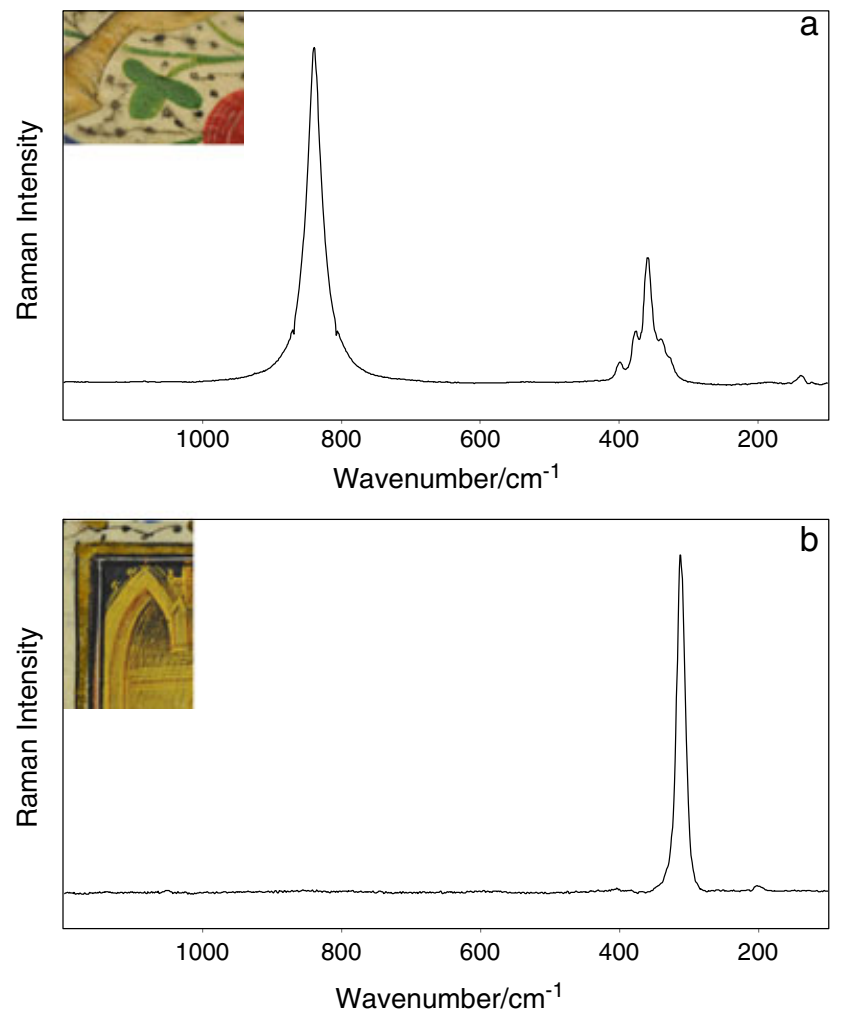

Figure 5. Raman spectra $(\lambda: 785 \mathrm{~nm}, 30 \times 5 \mathrm{~s}$, STD lens, $70 \mathrm{~mW}$, external power source) of: (a) Raman spectra of the unknown green colour in the border decoration, with bands at 840 and $358 \mathrm{~cm}^{-1}$ that can be assigned to chrome yellow $\left(\mathrm{PbCrO}_{4}\right)$; and (b) Raman spectra of the unknown gold colour in the miniature with characteristic band at $313 \mathrm{~cm}^{-1}$ that can be assigned to mosaic gold $\left(\mathrm{SnS}_{2}\right)$.

signal. In the miniature, on the other hand, on several illuminations, the characteristic Raman band of mosaic gold $\left(\mathrm{SnS}_{2}\right)$ at $313 \mathrm{~cm}^{-1}$, corresponding to $v(\mathrm{SnS})$ symmetric stretching, was detected (Fig. 5b). ${ }^{[45]}$ However, its production and use in the middle ages is described repeatedly, ${ }^{[46,47]}$ the identification of mosaic gold in mediaeval manuscripts is rater rare. ${ }^{[4]}$ Probably its use was suppressed by other easily obtainable yellow pigments. ${ }^{[49]}$

On the basis of these results, one can conclude that the introduced Raman spectrometer was a helpful technique in the identification of the used materials. However, it must be mentioned that there are still pigments unidentified such as, amongst others, the yellow in the border decoration. Complementary, in situ techniques (such as XRF and FTIR reflectance) exist to support the obtained results and enrich the information. Because of limited access to the manuscript, these experiments could not be performed. Also micro-sampling techniques (e.g. Q-tip method) exist, but due to preciousness of the manuscript, sampling was not allowed.

\section{Conclusions}

It can be concluded that the introduced Raman spectrometer, EZRAMAN-I-Dual Raman system, is well suited for the identification of pigments in mediaeval manuscripts. It is discussed how the availability of two lasers leads to a more successful identification of pigments and what is the importance of stable positioning. Next to this, it is proved that the introduced Raman spectrometer is highly performant to allow pigment identification in a short time. Finally, the research was completed with an in situ test by characterising the pigments in the mediaeval manuscript De Civitate Dei (Ms.106). This resulted in the identification of pigments that are in agreement with the mediaeval artists' palette. However, the identification of chrome yellow suggests a modern (post 1800) restoration.

\section{Acknowledgements}

The library of cultural heritage is thanked, more specifically Dr. Ludo Vandamme, for the disposal of the mediaeval manuscript. Also thanks to Sylvia Lycke, Jolien Van Pevenage and Alessia Coccato for their practical help during the investigation of the manuscript. The research is financially supported by the European Commission, through the FP-7 MEMORI project 'Measurement, Effect Assessment and Mitigation of Pollutant Impact on Movable Cultural Assets. Innovative Research for Market Transfer' (http://www.memori-project.eu/memori.html).

\section{References}

[1] P. Dhamelincourt, P. Bisson, Microsc. Acta. 1977, 79, 267.

[2] R. J. H. Clark, Comptes Rendus Chim. 2002, 5, 7.

[3] B. Guineau, Stud. Conserv. 1984, 29, 35.

[4] A. Jurado-López, O. Demko, R. J. H. Clark, D. Jacobs, J. Raman Spectrosc. 2004, 35, 119.

[5] B. Wehling, P. Vandenabeele, L. Moens, R. Klockenkämper, A. von Bohlen, G. Van Hooydonk, M. De Reu, Mikrochim. Acta. 1999, 130, 253.

[6] A. Deneckere, M. De Reu, M. P. J. Martens, K. De Coene, B. Vekemans, L. Vincze, P. De Maeyer, P. Vandenabeele, L. Moens, Spectrochim. Acta. A. Mol. Biomol. Spectrosc. 2011, 80, 125.

[7] V. Košařová, D. Hradil, I. Němec, P. Bezdička, V. Kanický, J. Raman Spectrosc. 2013, 44, 1570.

[8] R. J. H. Clark, P. J. Gibbs, J. Archaeol. Sci. 1998, 25, 621-629.

[9] L. Burgio, D. A. Ciomartan, R. J. H. Clark, J. Raman Spectrosc. 1997, $28,79$.

[10] L. Burgio, D. A. Ciomartan, R. J. H. Clark, J. Mol. Struct. 1997, 405, 1.

[11] S. P. Best, R. J. H. Clark, M. Daniels, C. A. Porter, R. Withnall, Stud. Conserv. 1995, 40, 31

[12] S. Pessanha, M. Manso, M. L. Carvalho, Spectrochim. Acta Part B At. Spectrosc. 2012, 71-72, 54

[13] S. Bruni, F. Cariati, F. Casadio, V. Guglielmi, J. Cult. Herit. 2001, 2, 291.

[14] L. Burgio, R. J. H. Clark, S. F. Muralha, T. Stanley, J. Raman Spectrosc. 2008, 39, 1482.

[15] K. Trentelman, N. Turner, J. Raman Spectrosc. 2009, 40, 577.

[16] M. Aceto, A. Agostino, G. Fenoglio, P. Baraldi, P. Zannini, C. Hofmann, E. Gamillscheg, Spectrochim. Acta. A. Mol. Biomol. Spectrosc. 2012, 95, 235.

[17] S. Bruni, V. Guglielmi, springer proceedings in physics Springer, Berlin, 2007.

[18] P. Vandenabeele, B. Wehling, L. Moens, B. Dekeyzer, Analyst. 1999, 124, 169.

[19] S. P. Best, R. J. H. Clark, R. Withnall, Ende 1992, 16, 66.

[20] L. Burgio, R. J. H. Clark, R. R. Harck, PNAS. 2012, 107, 5726.

[21] K. Trentelman, N. Turner, J. Raman Spectrosc. 2009, 40, 577.

[22] A. Deneckere, M. Leeflang, M. Bloem, C. Chavannes-Mazel, B. Vekemans, L. Vincze, P. Vandenabeele, L. Moens, Spectrochim. Acta. A. Mol. Biomol. Spectrosc. 2011, 83, 194.

[23] D. Bersani, P. Lottici, F. Vignali, G. Zanichelli, J. Raman Spectrosc. 2006, 37, 1012.

[24] P. Vítek, E. M. A. Ali, H. G. M. Edwards, J. Jehlička, R. Cox, K. Page, Spectrochim. Acta. A. Mol. Biomol. Spectrosc. 2012, 86, 320.

[25] P. Vandenabeele, Practical Raman spectroscopy: An introduction, John Willey \& Sons, United Kingdom, 2013.

[26] R. L. McCreery, Raman spectroscopy for chemical analysis. Chapter 1: introduction and scope, John Willey \& Sons, New York, 2000.

[27] D. Lauwers, A. G. Hutado, V. Tanevska, L. Moens, D. Bersani, P. Vandenabeele, Spectrochim. Acta. A. Mol. Biomol. Spectrosc. 2013, 118, 294.

[28] P. Vandenabeele, H. G. M. Edwards, J. Jehlička, Chem. Soc. Rev. 2013; DOI: 10.1039/c3c560263J. 
[29] G. Bousmanne, Guillaume Wielant of Willem Vrelant: Miniaturist aan het Bourgondische Hof in de 15de eeuw, Royal Library of Belgium, Brussel, 1997.

[30] F. Lyna, Onbekende handschriften verlucht door Willem Vrelant en zijn atelier, Gentse Bijdrage tot de Kunstgeschiedenis, De Sikkel, Antwerp, 1943.

[31] http://cabrio.bibliotheek.brugge.be/browse/webgaleries/MS106/index.html.

[32] W. Le Loup et al., Vlaamse kunst op perkament: handschriften en miniaturen te Brugge van de 12de tot de 16de eeuw, Stad Brugge, Brugge, 1981.

[33] A. Derolez, Besloten wereld, open boeken: middeleeuwse handschriften in dialoog met actuele kunst, Lannoo, Tielt, 2002.

[34] P. Vandenabeele, K. Castro, M. Hargreaves, L. Moens, J. M. Madariaga, H. G. M. Edwards, Anal. Chim. Acta. 2007, 588, 108.

[35] P. Vandenabeele, T. L. Weis, E. R. Grant, L. J. Moens, Anal. Bioanal. Chem. 2004, 379, 137.

[36] R. T. Downs, 19th General Meeting of the International Mineralogical Association, Kobe, Japan, 2006, 003-13, RRUFF, http://rruff.info/.

[37] P. Vandenabeele, L. Moens, Non-destructive microanalysis of cultural heritage materials, Elsevier, Amsterdam, 2004.

[38] A. Derolez, The Palaeography of Gothic Manuscript Books: From the Twelfth to the Early Sixteenth Century, Cambridge University Press, Cambridge, 2006.

[39] H. H. Willard, L. L. Meritt, J. A. Dean, F. A. Settle, Instrumental methods of analysis, Wadsworth Pub. Co., Belmont (California), 1981.
[40] J. R. Wigelsworth, Science and Technology in Medieval European Life, Greenwood Press, Westport, 2006.

[41] L. Arvin, Scribes, script and books: the book arts from antiquity to the Renaissance, American Library Association, Chicago, 1991.

[42] H. G. M. Edwards, D. W. Farwell, C. J. Brooke, Anal. Bioanal. Chem. 2005, 383, 312.

[43] D. V. Thompson, The materials and techniques of mediaeval painting, Dover Publications Inc., New York, 1956.

[44] L. Burgio, D. A. Ciomartan, R. J. H. Clark, J. Raman Spectrosc. 1997, 28, 79.

[45] H. G. M. Edwards, D. W. Farwell, E. M. Newton, F. R. Perez, S. J. Villar, J. Raman Spectrosc. 2000, 31, 407.

[46] H. G. M. Edwards, E. L. Dixon, I. J. Scowen, F. R. Perez, Spectrochim. Acta Part A-Molecular Biomol. Spectrosc. 2003, 59, 2291.

[47] D. Gulotta, S. Goidanich, M. Bertoldi, S. Bortolotto, L. Toniolo, Archaeometry. 2012, 54, 940.

[48] J. L. Ross, Stud. Conserv. 1973, 18, 174.

[49] M. Merrifield, Original Treatises Dating from the XIlth to the XVIIIth Centuries on the Art of Painting, John Murray, London, 1849.

\section{Supporting information}

Additional supporting information may be found in the online version of this article at the publisher's web site. 